\title{
Attitudes of the Local Population and Business Stakeholders on the Impact of Cruise Tourism on Destination
}

\section{Stavovi lokalnog stanovništva i poslovnih dionika o utjecaju turizma kružnih putovanja na odredište}

\author{
Luka Vukić \\ University of Split \\ Faculty of Maritime Studies \\ Croatia \\ E-mail: luka.vukic@pfst.hr
}

\author{
Vice Mihanović \\ Port Authority Split \\ E-mail:vice.mihanovic@gmail.com
}

\author{
DOI 10.17818/NM/2021/1.5 \\ UDK 338.48:629.541 \\ 314.117-054.51 \\ Review / Pregledni rad \\ Paper accepted / Rukopis primljen: 3. 6. 2020
}

\section{Summary}

The impact of cruise tourism on key stakeholders determines further development of the cruise industry on a destination, imposing an obligation to systematically and continuously monitor stakeholders' perceptions and attitudes. During 2019, primary research was conducted to examine two keys components of the cruise activity at the destination: the impact of cruise tourism on the local population and stakeholders performing business activities in the port of Split. Two individual groups of survey questionnaires were created. Special attention was given to the social, economic, and environmental impacts of cruise tourism, respecting the principles of sustainable development. These values were estimated based on the Likert scale. The local population considers the economic and social effects of cruise tourism as exceedingly positive and is more prepared for tolerance and resilience to achieve the expected well-being. Local business stakeholders are more restrained and record a minimal increase in income and employment related to the cruise activity. Limited perception and knowledge on sustainable development in the port of Split are characteristic of both groups of respondents.

\section{Sažetak}

Utjecaj turizma kružnih putovanja na ključne dionike određuje daljnji razvoj te industrije u odredištu, namećući obvezu sustavnog i kontinuiranog praćenja percepcija i stavova dionika. Tijekom 2019. provedeno je primarno istraživanje kako bi se ispitale dvije ključne sastavnice aktivnosti kružnih putovanja u odredištu: utjecaj turizma kružnih putovanja na lokalno stanovništvo i dionike koji obavljaju poslovne aktivnosti u splitskoj luci. Kreirane su dvije skupine anketnih upitnika. Posebna pažnja posvećena je socijalnim, ekonomskim i ekološkim utjecajima krstarenja, poštujući načela održivog razvoja. Te vrijednosti procijenjene su na temelju Likertove skale. Lokalno stanovništvo ekonomske i socijalne učinke turizma kružnih putovanja smatra izuzetno pozitivnim $i$ spremno je za toleranciju i fleksibilnost kako bi se postigla očekivana dobrobit. Dionici lokalnih poduzeća suzdržaniji su i bilježe minimalan porast dohotka i zaposlenosti vezanih uz krstarenje. Ograničena percepcija i znanje o održivom razvoju u splitskoj luci karakteristični su za obje skupine ispitanika.

\section{KEY WORDS}

cruise tourism local population business stakeholders port of Split

\section{INTRODUCTION / Uvod}

The impact of cruise ship traffic on a destination will proportionally determine the future approach to the development of cruise industry from the destination's perspective. There is an imposed obligation to systematically and continuously monitor and analyze its impact on the various components of the destination. The impact can be categorized into two groups, the positive consequences that contribute to social and economic development, including the establishment and recognition of the destination, and some negative consequences that are primarily directed at environmental pollution and threat to the sustainable development of the destination.

The social component of sustainable development is primarily related to the impact of cruise economic activity on residents and its implications on the quality of daily life of the local population in interaction with cruise visitors and vessels at the destination.
Stakeholder analysis, also known as the analysis of entities having a significant interest in the activity, analyzes business activities on which the development and sustainability of their companies depend. The effectiveness of cruise tourism depends on a large scale of cooperation, coordination, and interaction between stakeholders in the process of creating a unique and successful product or service.

The port of Split is the largest Croatian passenger port and third busiest East-Mediterranean passenger port with an annual traffic of more than 5.4 million passengers recorded in 2018. In 2018 , there were 260 cruise ship arrivals with a total of 307,148 passengers, making Split the second most important cruise port in Croatia, just behind Dubrovnik [6]. Cruise line activity in the port of Split has been steadily increasing over the last ten years, generating a direct annual revenue estimated at around $€ 15$ 
million in 2018 [20]. The city of Split as a cruise destination has yet to develop a clear vision for the development of cruise tourism, not excluding the possibility of cruise home port establishment. In this regard, the key stakeholder analysis is necessary to determine the supporting and opposing assumptions of each entity interested in the industry.

During 2019, primary research was conducted to examine two key components of cruise activity at the destination: the impact of cruise tourism on the local population and impact of cruise industry on stakeholders performing business activities in the port of Split. For this purpose, two individual groups of survey questionnaires were created. Respecting the principles of sustainable development, the particular attention was given to the social, economic, and environmental impact of cruise tourism. This primary research has provided essential data from the emissive market intending the affirmation, prosperity and further development of cruise services supply, either from the destination or port perspective, in accordance with the market guidelines from cruise travel demand standpoint at Split cruise destination.

\section{LITERATURE REVIEW / Pregled literature}

The development of cruise tourism implies, among other business decisions, significant investments in cruise infrastructure, so when considering the access to this tourism industry regular research and planning is required [12]. In order to maintain the existing level of activity, investments in innovation are required, while respecting the criteria of social and environmental responsibility [21]. Cruise tourism affects the destination with its socio-cultural, economic, and environmental effects [16]. Economic and social impacts on the destination can have a positive or negative effect, while the impact on the environment is almost always negative, so it is necessary to adapt to the principles of sustainable development [2]. An obvious example is in the city of Venice where delayed adaptation has caused pollution of the natural and cultural heritage of such proportions that it endangers the normal life of citizens who therefore require very strict regulations for cruising [23]. Assessing residents' perceptions, as principal local stakeholders, is a crucial stage before investing in any product in tourism [25]. Cruise passengers, crew, and residents are crucial to the satisfaction of visitors and the success of the tourist destination [7]. The perceptions of both local stakeholders and residents, also considering their relationship to the impact of any proposed tourism development model, should be considered when planning the future development of a cruise tourism destination [8If stakeholders support the development of tourism, then they will support investments and projects, will more easily tolerate harmful effects and will better accept guests to make them more satisfied [22]. Uran Maravic et al. [24] recommend the development of a detailed methodology for local communities to monitor the effects of cruise tourism at their local destination. All entities are obligated to adjust their businesses and operate as partners, including cluster creation, in order to enhance positive and reduce negative consequences [5]. Pivcevic et al. [18] believe that promotion, revenue, and job creation are the most pronounced positive impacts of cruise tourism, and the impact on stationary tourists is the most negative one. Linking the sustainable development paradigm to the cruise activity can provide a solution to the challenges that the industry is facing [1]. A focus on the perception of the local communities leads to more effective addressing of residents' issues [11]. Pino and Peluso [17] identify four basic factors for successful business performance in cruise tourism, namely the availability of resources, provision of integrated services, stakeholder collaboration, and branding of destination. The residents and local business stakeholders are responsible for all four development requirements. Passenger satisfaction that is achieved through harmonious action of all stakeholders increases passenger consumption [10]. Proper interaction and trust are the main prerequisites for a successful joint action [19]. Generally, residents have a positive perception of the presence of cruise tourism in the destination, but they are also aware of the negative impacts on their well-being [3]. Peručić and Puh [15] recommend continuous market research and analysis in the city of Dubrovnik with an emphasis on solving burning issues that reduce the quality of life of the local population. Despite this, Lučić et al. [13] observe an average negative perception of the effects of cruise tourism in the city of Dubrovnik, especially those citizens who live closer to the tourist attractions in the city center. The cluster analysis in the city of Valencia shows similar results and highlights the doubts of residents about the benefits of this type of tourism [9]. Positive attitudes of local stakeholders enable the creation and development of a local strategy aimed at improved management of present and future cruise line visits [14].

Based on the presented indicators of cruise tourism and literature review, a survey of the perception of the local population and interested business stakeholders is conducted in order to plan investments in the further development of the cruise industry in the city of Split. Such research has not been conducted so far.

\section{METHODOLOGY / Metodologija}

The impact of cruise tourism on the local population has been measured and evaluated by conducting a field research in the form of a structured questionnaire and personal interview in the city of Split during the third and fourth quarter of 2019. The research was based on a sample of 366 respondents, where 168 residents reported the city center as a place of their residence, along with remaining 198, which were situated in the other parts of the city. The questionnaire was structured and grouped into 20 impact elements, and the values offered were estimated based on the Likert scale (from 1 - strongly disagree, to 5 strongly agree). Generally, a survey questionnaire was divided into four categories, from the aspect of assessing the impact of cruise tourism on local population, as follows:

- General perception on cruising,

Economic implications of cruise tourism,

Ecological implications of cruise tourism,

Perspective and sustainable development.

During the fourth quarter of 2019, the analysis of business stakeholders from the local community on evaluation of performance of the cruise industry in Split was conducted on the sample of 17 relevant stakeholders of different profiles and services, using the questionnaire structured according to four survey categories:

Economic effects,

Environmental issues,

Social impact, 
- Impact of cruise tourism on cultural heritage.

Considering that the port of Split is classified as a transit port in the cruise market, the services offered were categorized as the destination and port services, mainly concentrated on the "oncruise" segment of services value chain. The primary survey included a total of 17 stakeholders, nine of which (53\%) were involved in the destination services while the remaining eight (47\%) were involved in the port service activities. The types of services offered in Split as a cruise destination are shown in Table 1.

Table 1 Types of stakeholders' services in cruise tourism in Split Tablica 1. Vrste usluga dionika u turizmu kružnih putovanja u Splitu

\section{DESTINATION SERVICES}

- promotion of the tourist activity of

the city of Split

- shopping

- tour guides

- taxi services

- souvenir sales

- excursion programs

- boat transfers

- cultural and historical institutions

- restaurant and bar services

Source: Created by authors

Respondents were offered some answers in the questionnaire to assess the economic effects, while the Likert scale (1 - strongly disagree; 5 - strongly agree) was used to evaluate the remaining impact elements.

\section{SURVEY RESULTS / Rezultati ankete}

Almost half of the respondents (49.2\%), residents in the city of Split, confirmed the statement that cruise passengers create congestion in the city center during the high summer season, however, the perception of cruise activity in the destination by locals is generally positive. This perception is supported by a high percentage of respondents' answers to the following claims:

- Cruise activity has a positive impact on the overall tourism supply portfolio of the city of Split, where 39.3\% of respondents agreed with this statement, and $29.5 \%$ completely agreed with the positive impact of cruise activity, Cruise vessels contribute to the positive image of the city of Split, where $31.1 \%$ of respondents agreed with this statement, $23.0 \%$ completely agreed while $27.9 \%$ had an average level of satisfaction with the rated issue,

- Cruise tourism diminishes the recognition of Split as a tourist destination, where $34.4 \%$ of respondents disagreed with this statement, $24.6 \%$ completely disagreed while $24.6 \%$ of respondents neither disagreed nor agreed with the stated criteria,

- The activity of cruise liners is important for Split as a tourist destination, where $27.9 \%$ of respondents had a positive perception of the statement, while $34.4 \%$ expressed an extremely positive level of satisfaction,

- Cruise tourism has a negative impact on stationary tourism at the destination, where $42.6 \%$ of respondent selected a moderate scale rate, while $26.2 \%$ disagreed with the abovementioned statement.

The residents' attitudes in the context of a negative cruise tourism impact on their quality of daily life were largely restrained, with $42.6 \%$ of them selecting a median level of scale and $24.6 \%$ disagreed with the examined statement. Also, most of the respondents (62.3\%) considered the cruise tourism activity to have more positive than negative implications for Split as a tourist destination.

An overview of residents' feedback on the economic effects of cruise tourism is shown in Table 2.

When assessing the economic benefits of cruising in Split, the consistency in perception is evident, where $42.6 \%$ of respondents had a positive attitude, and $32.8 \%$ agreed with observations on the significant implications of cruising line activity in Split. It should be noted that over half of respondents have a moderate level of satisfaction with the indirect personal benefits of cruise tourism.

Assessment of local inhabitants' attitudes on the environmental impacts of cruise tourism at the destination of Split is shown in Table 3.

Table 2 Attitudes of local population on cruise tourism, based on estimates of economic indicators Tablica 2. Stavovi lokalnog stanovništva o turizmu kružnih putovanja na temelju procjena ekonomskih pokazatelja

\begin{tabular}{|c|c|c|c|c|c|}
\hline \multirow[t]{2}{*}{ Statement } & \multicolumn{5}{|c|}{ Level of agreement* } \\
\hline & 1 & 2 & 3 & 4 & 5 \\
\hline Cruise tourism generates a positive economic impact in Split & $8,2 \%$ & $6,6 \%$ & $9,8 \%$ & $42,6 \%$ & $32,8 \%$ \\
\hline Cruise tourism produces indirect personal benefits & $4,9 \%$ & $8,2 \%$ & $50,8 \%$ & $29,5 \%$ & $6,6 \%$ \\
\hline Cruise tourism produces direct personal benefits & $11,5 \%$ & $13,1 \%$ & $26,2 \%$ & $34,4 \%$ & $14,8 \%$ \\
\hline Cruise tourism generates employment in Split & $4,9 \%$ & $9,8 \%$ & $29,5 \%$ & $36,1 \%$ & $19,7 \%$ \\
\hline \multirow[t]{2}{*}{ Estimation of passenger consumption from cruise ship in the destination } & $<20 €$ & $30-40 €$ & $50 €$ & $60-90 €$ & $>100 €$ \\
\hline & $3,3 \%$ & $19,7 \%$ & $44,3 \%$ & $23,0 \%$ & $9,8 \%$ \\
\hline
\end{tabular}

*1 - strongly disagree; 5 - strongly agree

Source: Created by authors

Table 3 Attitudes of the local population towards cruise tourism, based on the assessment of ecological indicators Tablica 3. Stavovi lokalnog stanovništva o turizmu kružnih putovanja na temelju procjene ekoloških pokazatelja

\begin{tabular}{|c|c|c|c|c|c|}
\hline \multirow[t]{2}{*}{ Statement } & \multicolumn{5}{|c|}{ Level of agreement * } \\
\hline & 1 & 2 & 3 & 4 & 5 \\
\hline Cruise ships - sources of water pollution in the port of Split & $6.6 \%$ & $13.1 \%$ & $18.0 \%$ & $39.3 \%$ & $23.0 \%$ \\
\hline Cruise ships - generate waste increase in the port of Split & $3.3 \%$ & $6.6 \%$ & $29.5 \%$ & $34.4 \%$ & $26.2 \%$ \\
\hline
\end{tabular}

* 1 - strongly disagree; 5 - strongly agree

Source: Created by authors 
Table 4 Attitudes of the local population towards cruise tourism based on the assessment of the sustainable development of the destination Tablica 4. Stavovi lokalnog stanovništva o turizmu kružnih putovanja na temelju procjene održivog razvoja odredišta

\begin{tabular}{|c|c|c|c|c|c|}
\hline \multirow[t]{2}{*}{ Statement } & \multicolumn{5}{|c|}{ Level of agreement * } \\
\hline & 1 & 2 & 3 & 4 & 5 \\
\hline Necessity to limit the number of cruisers in high summer months & $3.3 \%$ & $11.5 \%$ & $19.7 \%$ & $24.6 \%$ & $41.0 \%$ \\
\hline $\begin{array}{l}\text { Dispersion of cruise line arrivals throughout the year as a measure to increase the } \\
\text { quality of both visitors stay and everyday life of local population }\end{array}$ & $1.6 \%$ & $3.3 \%$ & $24.6 \%$ & $39.3 \%$ & $31.1 \%$ \\
\hline Development of cruise tourism by local authorities & $6.6 \%$ & $4.9 \%$ & $19.7 \%$ & $45.9 \%$ & $23.0 \%$ \\
\hline Development of cruise tourism in correlation with the sustainable development of the city & $4.9 \%$ & $11.5 \%$ & $37.7 \%$ & $31.1 \%$ & $14.8 \%$ \\
\hline
\end{tabular}

* 1 - strongly disagree; 5 - strongly agree

* 1 - potpuno se ne slažem; 5 - potpuno se slažem

Source: Created by authors

The perception of the local population, considering the environmental impact of cruise tourism in Split, is generally negative and disproportional to the overall perception towards cruise tourism in Split. Respondents agreed with the statement that cruise vessels are significant sources of water pollution and air pollution in the port of Split while also contributing to the increase in waste production.

The remaining part of the survey on attitudes and perception of the local population with cruise tourism was related to examining the perspective for destination's sustainable development and is presented in Table 4.

Respondents fully agreed on the necessity to limit the number of cruise ships in high summer months as modeled on the port of Dubrovnik. They mostly agreed that the dispersion of cruise line arrivals throughout the year would result in an increased quality of both visitors' stay and the daily life of the local population. Almost half of the respondents advocated further development of cruise tourism by the local authorities in Split. Less than half of the respondents support the statement that the development of cruise tourism is in correlation with the sustainable development of the city of Split, and more than 1/3 of them have not an attitude toward it.

The analysis of the collected results revealed an almost analogous attitude of the local population living in the tourist activity zone (45.9\% of the total amount of the respondents) and the perception of the overall number of respondents regarding cruise tourism, therefore the additional analysis was omitted.

When assessing the economic impact of cruise tourism activity on business performance of local stakeholders, the following elements were examined: total revenue share from cruise activity relative to the entire business, increase in revenue from cruise business activity compared to the previous period, range of products or services offered on the market, operating costs generated in the local businesses, and share of direct and indirect employed personnel in cruise related business units regarding the total number of employees, everything related to cruise tourism activities. The results of cruise tourism economic impact on business performance of selected stakeholders are shown in Figure 1.

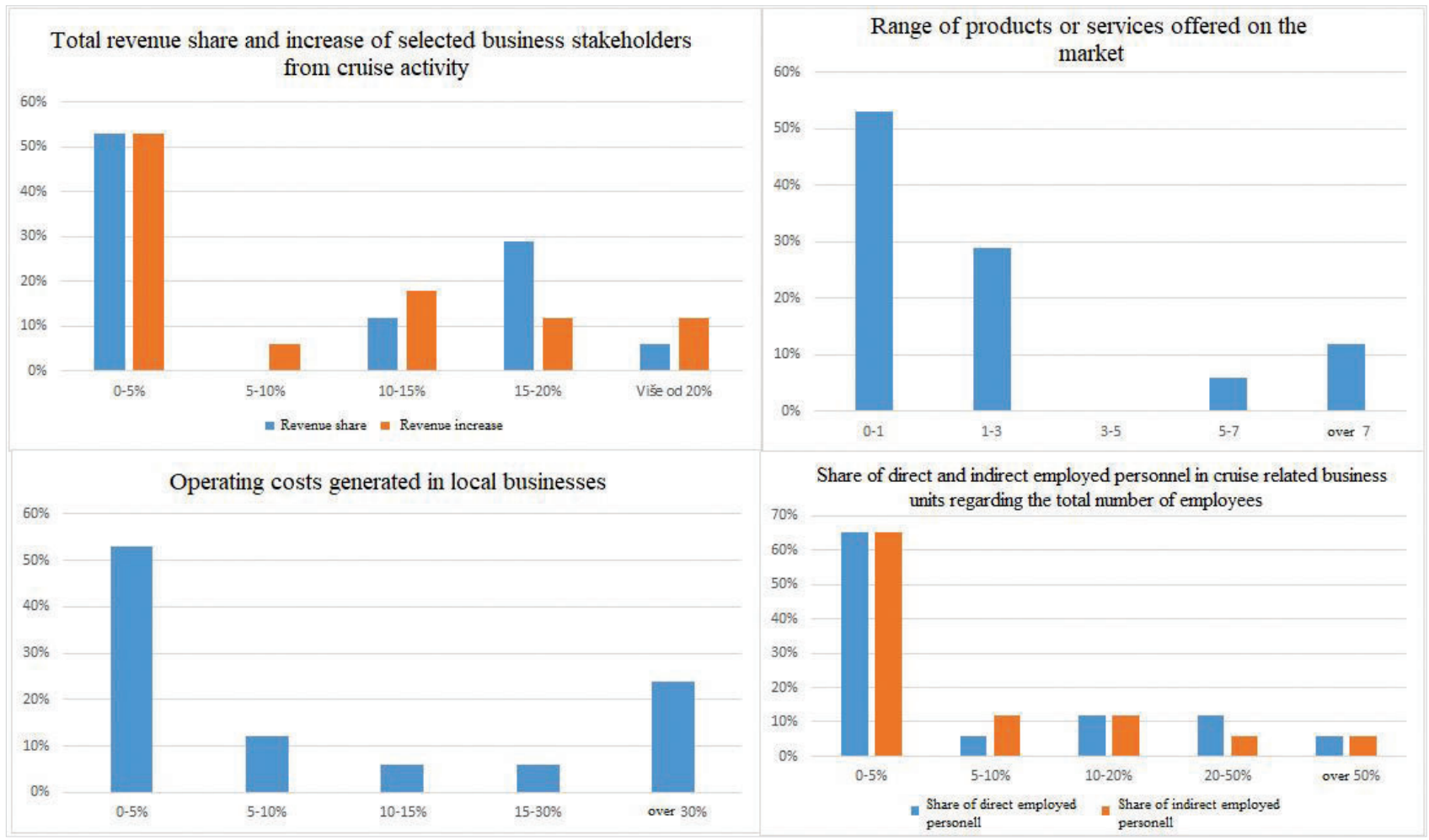

Figure 1 Economic impact of cruise line activities on businesses of selected stakeholders Slika 1. Ekonomski utjecaj aktivnosti krstarenja na poslovanje odabranih dionika

Source: Created by authors 
The results of the economic effects of cruise tourism on business performance of selected stakeholders indicated the highest representation of the first group of proposed distribution (0-5\%), which dominated as a selection, having over $50 \%$ share of all criteria examined. Also, $53 \%$ of stakeholders determined a range of " $0-1$ " of product/service offered in the destination Split as a part of their business portfolio.

The second examined category of questionnaire, intended for the business stakeholders, was the assessment of the cruise environmental impacts. The only representative sample of overall responses, among the examined ones, were found in the category of the assessment of negative impact of cruise tourism on the local natural heritage from the perspective of local population. The evaluation of remaining environmental categories, which included the amount of ship-generated waste from cruise ships, the share of recycled ship-generated waste in the port, the existence or absence of static waste collection facilities and the proportion of the five most visited, protected, natural sights in the total number of visited destinations promoted through cruise tourism, referred exclusively to the evaluation of relevant business stakeholders of that specific activity. The results are presented in Table 5 .

More than a third of respondents (35\%) indicated a predominantly neutral attitude in assessing the impact of the cruise industry on the local natural heritage of the city of Split, while a respectable share of $29 \%$ of stakeholders considered the significant negative impact of cruise tourism on local natural heritage.

The evaluation of criterion, in the context of the share of the five most visited, protected, natural landmarks in the total number of visited destinations significantly promoted through cruise tourism, was performed from the perspective of the relevant business stakeholders. Tourist Board of Split is responsible for promoting tourism of the city of Split, providing hospitality and other tourism services or performing other activities directly related to tourism. According to the assessment of the activity holder, the share of the examined criterion was $25 \%$ and, for the purpose of this part of the analysis, is considered as representative.

The social impact assessment of cruise tourism in Split, as the third examined category, was analyzed on the basis of the following elements: the number of recently employed individual employees in the cruise tourism activity in the last three years and the indicators of governance at the destination of Split. The latter included the assessment of the following criteria: the level of satisfaction of the local population with cruise tourism, the accessibility levels of port infrastructure for passengers with disabilities and special needs, the level of accessibility of public transport of the city of Split for passengers with disabilities and special needs, and the intensity of annual, local, cultural events stimulated by cruise tourism. The selected business stakeholders indicated an average value of two (2) new employees, in the total number of recently employed personnel in the last three years regarding the cruise activity area, while governance indicators in cruise destination Split were valorized using the Likert scale (Table 6).

Analyzing the indicators of governance in Split assessed by the business stakeholders, a mediocre attitude of most business stakeholders was noticeable, estimating the level of satisfaction of the local population with cruise tourism as well as the intensity of annual local cultural events stimulated by cruise tourism. When assessing the accessibility level of the port infrastructure and public transportation in the city of Split for passengers with disabilities and special needs, a generally positive attitude was shown.

The last analyzed category referred to the impact of cruise tourism on cultural heritage of the city of Split, where the following elements were evaluated:

perception of the positive impact of cruise tourism on the identity of the city of Split and the cultural heritage form the aspect of the local population,

- share of major destination traditional/cultural events, which are significantly promoted by cruise tourism,

share of the most important traditional/cultural destinations, significantly promoted by cruise tourism,

level of accessibility of excursion sites (cultural and historical) in Split for tourists with special needs.

The estimation of the share of the most important destination traditional/cultural events, which are significantly promoted by cruise tourism and the most important destination traditional/ cultural sights, which are significantly promoted through/by

Table 5 Impact of cruise tourism on local natural heritage from the perspective of selected business stakeholders Tablica 5. Utjecaj turizma kružnh putovanja na lokalnu prirodnu baštinu iz perspektive odabranih poslovnih dionika

\begin{tabular}{|c|c|c|c|c|c|}
\hline \multirow{2}{*}{ Statement } & \multicolumn{5}{|c|}{ Level of agreement * } \\
\hline & 1 & 2 & 3 & 4 & 5 \\
\hline Negative impact of cruise tourism on the local natural heritage & $29 \%$ & $6 \%$ & $35 \%$ & $18 \%$ & $12 \%$ \\
\hline
\end{tabular}

* 1 - strongly disagree; 5 - strongly agree

Source: Created by authors

Table 6 Evaluation of governance indicators by selected business stakeholders in Split Tablica 6. Procjena odabranih poslovnih dionika u Splitu o indikatorima upravljanja

\begin{tabular}{|c|c|c|c|c|c|}
\hline \multirow{2}{*}{ Statement } & \multicolumn{5}{|c|}{ Level of agreement * } \\
\hline & 1 & 2 & 3 & 4 & 5 \\
\hline Level of satisfaction of locals with cruise tourism & $29 \%$ & $18 \%$ & $35 \%$ & $12 \%$ & $6 \%$ \\
\hline Level of accessibility of port infrastructure for passengers with disability and special needs & $12 \%$ & $0 \%$ & $29 \%$ & $41 \%$ & $18 \%$ \\
\hline $\begin{array}{l}\text { Level of accessibility of public transport in the city of Split for passengers with disability } \\
\text { and with special needs }\end{array}$ & $6 \%$ & $18 \%$ & $29 \%$ & $35 \%$ & $12 \%$ \\
\hline Intensity of annual local cultural events stimulated by cruise tourism & $35 \%$ & $0 \%$ & $53 \%$ & $6 \%$ & $6 \%$ \\
\hline
\end{tabular}

* 1 - strongly disagree; 5 - strongly agree

Source: Own elaboration 
Table 7 Business stakeholder assessment of the cruise tourism impact on the cultural heritage of the city of Split Tablica 7. Procjena poslovnih dionika o utjecaju turizma kružnih putovanja na kulturnu baštinu grada Splita

\begin{tabular}{|c|c|c|c|c|c|}
\hline \multirow{2}{*}{ Statement } & \multicolumn{5}{|c|}{ Level of agreement * } \\
\hline & 1 & 2 & 3 & 4 & 5 \\
\hline $\begin{array}{l}\text { Residents' perception on the positive implications of cruise tourism influencing the identity of the } \\
\text { city of Split and the local cultural heritage }\end{array}$ & $24 \%$ & $12 \%$ & $29 \%$ & $24 \%$ & $12 \%$ \\
\hline Level of accessibility of excursion sites (cultural and historical) in Split for travelers with special needs & $12 \%$ & $18 \%$ & $29 \%$ & $29 \%$ & $12 \%$ \\
\hline
\end{tabular}

Source: Created by authors

cruise tourism, was based on the evaluation and feedback from the Tourist Board of Split, a stakeholder operating as a promoter of the tourist activity of the city of Split. The assessment of the examined elements showed that $20 \%$ of the most important traditional/ cultural destination events are considered to be significantly promoted through cruise tourism, and $80 \%$ of the most important traditional/cultural destinations that are found to be significantly promoted through cruise tourism. The remaining analyzed elements, valorized by the Likert scale, are shown in Table 7.

The selected Split cruise tourism business stakeholders assessed the perception of the local population on the positive implications of cruise tourism influencing the identity of the city of Split and the local cultural heritage with an overall average level of satisfaction. The similar stakeholders' assessment rate was also for the level of accessibility of excursion sites (cultural and historical) in Split for travelers with special needs, but recording a slightly higher share of satisfaction.

\section{DISCUSSION / Rasprava}

Differently than in neighboring Dubrovnik [13], there are mostly positive attitudes of residents of the city of Split towards cruise tourism, which is particularly evident in simplified interpretation of structured questionnaire reducing evaluation of the agreement levels to only three elements of the Likert scale $(1+2=$ disagree; $3=$ not clear attitude - middle level; $4+5$ $=$ agree). . There is no difference in the attitudes of citizens living in the center of Split and on the outskirts. The local population recognized cruise tourism as a significant economic activity that generates positive economic impact, employment, and generally more benefits to the destination. As in Dubrovnik and Valencia $[9,15]$, the citizens of Split are aware of the harmful consequences of this industry but far from doubting the benefits. Even though cruise ship visitors contribute to the increased level of congestion at the destination, they are prepared to tolerate it for public interest and positive economic impact on the prosperity and affirmation of the city and community. They also believed that cruise liners contribute to positive effects on the identity of the itinerary and that the recognition of the destination is not compromised. Despite the positive standpoint of the local population on cruise tourism, the results of the conducted questionnaire indicated some deficiencies. There are also potentially detrimental factors, which should be addressed, especially a perception related to intensifying the development of this economic activity followed by daily intensive congestion during the high summer season, which is assessed as the main difficulty. The local population is still unable to estimate the real indirect benefits for the destination generated by the consumption of visitors, but also the impact of cruise tourism on the quality of daily life. The residents were incapable of assessing the impact of cruise tourism on stationary guests but, they were in favor of implementing measures to limit the number of cruise ships in the high summer months of a tourist season. Assuming that the dispersion of cruise ship arrivals throughout the whole year would increase the level of quality of tourist stay and the quality of life of the local population, they supported the further development of cruise activity. However, 54\% of them express uncertainty regarding the future of cruise tourism in line with the sustainable development of the city of Split.

The analysis of business stakeholder attitudes from the local community provided significant results of the primary research, which was based on the assessment of economic, environmental, and social impacts of cruise tourism as well as the effect on the cultural heritage of the city of Split. The economic impact of cruise activity on individual stakeholder businesses indicated the positive implications of cruise tourism on their business performance, assessing it as an increase in revenue of up to $5 \%$. Furthermore, several stakeholders had a considerable increase in the range of activities, depending on the function of the individual stakeholder in the value chain of supplied services and products, business specificity, and development perspective in the port of Split. However, the attitudes of business stakeholders are mostly skeptical because, according to the criteria of [18], they cite a modest increase in income and the creation of a minimum number of new jobs. They are also suspicious about the perception of the local population towards the cruise tourism in Split, thus expressing distrust of their partners, which according to [11], disables the main precondition for joint action. In the context of the cruise tourism impact on the environment, the business stakeholder analysis disclosed a medium (average) attitude on the cruise tourism negative impact on the local natural heritage, not denying that it complied with the suggested statement. Even 29\% of respondents strongly deny the harmful effect of cruise tourism on the environment. The cruise tourism social impact analysis by local stakeholders emphasized the low intensity of annual local cultural events stimulated by cruise tourism. They expressed a generally positive attitude when assessing the satisfaction level of the local population, referring to the quality of services for travelers with disabilities and special needs.

The last analyzed category was the assessment of cruise line impact on cultural heritage, which revealed a low proportion of the most important traditional/cultural events significantly promoted by cruise tourism. There is a satisfying share of the most significant, traditional/cultural destinations significantly promoted by cruise tourism. This assessment referred to a certain proportion of the supply segment at cruise tourism destination, where the adjustment and improvement of marketing activities, primarily to achieve maximum economic benefit from the activities, are needed. In assessing the remaining indicators on the impact of cruise liners on cultural heritage, business stakeholders estimated the satisfaction of locals 
as positive concerning the impact of cruise tourism on the identity of the city of Split and cultural heritage and the accessibility of the excursion sites (cultural and historical) in Split for travelers with special needs expressed a rather positive attitude. With the latter assessed element, a higher share of the business stakeholders was also satisfied.

Comparing the views of the residents and local stakeholders on cruise tourism it can be concluded that the residents had a more optimistic perception than business stakeholders. Their desires and expectations were greater and, despite their knowledge of the adverse effects, they were more prepared for tolerance and patience to achieve the expected well-being. While the local population considered the economic impacts of cruise tourism as exceedingly positive, the local business stakeholders were more restrained and showed a minimal increase in income and employment related to the activity. Although concerned about natural heritage, the business stakeholders did not offer any information about waste collection in the city port, which seems slightly paradoxical (except for the official activities concessionaire whose response was not evaluated as representative in the research). Their evaluation of residents' perception towards cruise tourism in the city was mostly negative, contrary to the perception expressed by the locals. It seems that the locals represented the broad interest of the city and the county, while the business stakeholders were more interested in private business results. Despite that, the residents very precisely estimated the average consumption of cruise tourists in the city of Split. That indicates the interest of residents in trends in cruise tourism by following them in public life and the media. Limited perception and knowledge on sustainable development in Split were characteristic to both groups of respondents. According to [1], the perception of sustainable development that should reconcile the positive and negative effects of cruise tourism has not been noticed in any group. Based on the results of the research, the positive perception of local stakeholders necessary to create a common strategy for the development and management of this tourism sector [8] has not been achieved.

\section{CONCLUSION / Zaključak}

The paper discusses the attitudes of key stakeholders on the positive and negative implications of cruise tourism in Split. By presenting valuable and useful data, enables objective analysis and planning in the industry for the first time. The local population and business stakeholders recognize cruise tourism in Split as a significant economic activity that generates positive economic impact, employment, and generally, more benefits for the destination. Although aware of the negative effect of this industry on the environment, the views of both groups of respondents are not entirely critically developed. Both entities of the cruise value chain need education on principles of sustainable development. Future investment in cruise tourism requires the joint action of all stakeholders. Differences in attitudes towards individual issues should overcome by strengthening mutual trust and cooperation. The small number of respondents in the group of business stakeholders is a limiting factor of this research, so the conclusions about their attitudes are approximate. Future research should be continuous and involve as many stakeholders as possible to objectively determine the timing of best conditions for investment.

\section{REFERENCES / Literatura}

[1] Asero, V., Skonieczny, S. 2018. Cruise Tourism and Sustainability in the Mediterranean - Destination Venice. In: Butowski, L. (ed.), Mobilities, Tourism and Travel Behavior Contexts and Boundaries, IntechOpen, DOI: 10.5772/ intechopen.68212. https://doi.org/10.5772/intechopen.71459

[2] Benić, I. (2011.). Influence of sea cruises on tourist destination. Poslovna izvrsnost 5: 43-66.

[3] Brida, J. G., Del Chiappa, G., Meleddu, M., Pulina, M. 2012. The perceptions of an island community towards cruise tourism: A factor analysis. Tourism:An International Interdisciplinary Journal 60: 29-42. https://doi.org/10.2139/ssrn.1994246

[4] Brida, J.G., Del Chiappa, G., Meleddu, M., Pulina, M. 2014. A Comparison of Residents' Perceptions in Two Cruise Ports in the Mediterranean Sea. Int. J. Tourism Res. 16: 180-190. https://doi.org/10.1002/jtr.1915. https://doi. org/10.1002/jtr.1915

[5] Brida, J. G., Riaño, E., Aguirre, S. Z. 2011. Residents' attitudes and perceptions towards cruise tourism development: A case study of Cartagena de Indias (Colombia). Tourism and Hospitality Research 11: 3, 181-196. https://doi. org/10.1177/1467358411415153

[6] CBS, Croatian Bureau of Statistics. 2019. Cruise travels of foreign vessels in the Republic of Croatia from January to December 2019. Zagreb, Croatia.

[7] Cruz Ruiz, E., Bermúdez González, G., Tous Zamora, D. 2018. Destination image, satisfaction and destination loyalty in cruise tourism: the case of Malaga (Spain). Tourism \& Management Studies, 14: 58-68, DOI: 10.18089/ tms.2018.14105. https://doi.org/10.18089/tms.2018.14105

[8] Del Chiappa, G., Gallarza, M. G., Zaragoza Viguer, A. 2013. Cruise Tourism Development in Valencia (Spain): Stakeholders' views and residents' attitude, accepted paper, In: Andreani, J. C., Collesei, U. (eds), Proceedings of the XIII International Conference Marketing Trends, Paris-Venice. Paris-Venice: Marketing Trends Association. ISBN 978-2-9532811-2-5.

[9] Del Chiappa, G., Lorenzo-Romero, C., Gallarza, M. 2016. Host community perceptions of cruise tourism in a homeport: A cluster analysis, Journal of Destination Marketing and Management 7:170-181. http://dx.doi.org/10.1016/j. jdmm.2016.08.011. https://doi.org/10.1016/j.jdmm.2016.08.011

[10] Jacobs, T. 2019. Assessment of the Economic Impact of Cruise Tourism in Fiji, Ministry of Industry, Trade and Tourism (MITT) of the Fijian Government, the Australian Government and the International Finance Corporation (IFC).

[11] Klein, R. A. 2011. Responsible Cruise Tourism: Issues of Cruise Tourism and Sustainability. Journal of Hospitality and Tourism Management 18: 107-116. DOI 10.1375/jhtm.18.1.107. https://doi.org/10.1375/jhtm.18.1.107

[12] London, W. R., Lohmann, G. 2014. Power in the context of cruise destination stakeholders' interrelationships. In: Pallis, A., Rodrigue, J. P., Notteboom, T. (eds.). Cruise and Cruise Ports: Structures and Strategies. Special Issue of Research in Transportation Business \& Management, Vol. 13, DOI:10.1016/j. rtbm.2014.11.004. https://doi.org/10.1016/j.rtbm.2014.12.002

[13] Lučić, I., Sindik, J., Manojlović, N. 2017. How do Dubrovnik Inhabitants Perceive the Cruise Tourism? Naše more, 64: 54-60 (Supplement). DOI 10.17818/NM/2017/2.10. https://doi.org/10.17818/nm/2017/2.10

[14] McCaughey, R., Mao, I., Dowling, R. 2018. Residents' perceptions towards cruise tourism development: the case of Esperance, Western Australia. Tourism Recreation Research 43: 3, 403-408. DOI: 10.1080/02508281.2018.1464098. https://doi.org/10.1080/02508281.2018.1464098

[15] Peručić, D., Puh, B. 2012. Attitudes of citizens of Dubrovnik towards the impact of cruise tourism on Dubrovnik. Tourism and hospitality management 18:213-228.

[16] Petroman, I., Petroman, C., Adamov, T., Negrut, L., Marin, D. 2017. The effects of cruising tourism on tourist destination. Lucrări Științifice, Seria l, Management Agricol 19: 173-176.

[17] Pino, G., Peluso, M. A. 2018. The development of cruise tourism in emerging destinations: Evidence from Salento, Italy. Tourism and Hospitality Research 18: 15-27, https://doi.org/10.1177/1467358415619672

[18] Pivčević, S., Mandić, A., Šalja, N. 2018. Government and business community attitudes towards cruise tourism development. Geographica Pannonica 22: 4, 285-294. https://doi.org/10.5937/gp22-18750

[19] Pomeranz, E. F., Needham, M. D., Kruger, L. E. 2013. Stakeholder Perceptions of Collaboration for Managing Nature Based Recreation in a Coastal Protected Area in Alaska. Journal of Park and Recreation Administration 31: 23-44.

[20] Port Authority of Split. 2019. Cruises. Available online at: https://portsplit.hr/ kruzna-putovanja [accessed November 275t, 2020].

[21] PratForga, J.M. 2016. Barcelona peopless perception of cruise tourism. Positive and negative impacts. The Economy Journal com. https://www.theeconomyjournal. eu/texto-diario/mostrar/591187/barcelona-peoples-perception-of-cruise-tourismpositive-and-negative-impacts, [accessed November $22^{\text {nd }}, 2020$ ].

[22] Sindik, J., Manojlović, N., Klarić, M. 2017. Perceived effects of the cruising tourism among residents of Dubrovnik. Ekonomska misao i praksa 26: 151-169.

[23] Trancoso González, A. 2018. Venice: the problem of overtourism and the impact of cruises. Investigaciones Regionales - Journal of Regional Research 42: 35-51.

[24] Uran Maravić, M., Gračan, D., Zirdum, Ž. 2017. Assessing impact of cruising tourism in Slovenia. Scientific Journal of Maritime Research 31: 27-32. https:// doi.org/10.31217/p.31.1.5

[25] Vernon, J., Essex, S., Pinder, D., Curry K. 2005. Collaborative Policymaking: Local Sustainable Projects. Annals of Tourism Research 32: 325-345. https:// doi.org/10.1016/j.annals.2004.06.005 